\title{
SILVER NANOPARTICLES FROM TRIANTHEMA PORTULACASTRUM: GREEN SYNTHESIS, CHARACTERIZATION, ANTIBACTERIAL AND ANTICANCER PROPERTIES
}

\author{
GOWRI SHANKAR K*, NAMRATA PRADHAN, MASILAMANI K, ALBIN T FLEMING
}

Department of Advanced Zoology and Biotechnology, Loyola College, Chennai, Tamil Nadu, India. Email: gowririshankar.88@gmail.com.

Received: 18 November 2016, Revised and Accepted: 30 November 2016

ABSTRACT

Objective: In this study, silver nanoparticles (SNPs) were synthesized using an aqueous extract of Trainthema portulacastrum and silver ions (Ag+) which have been proven against certain pathogenic bacterial strains and hepatocellular carcinoma (HepG2) cell line.

Methods: The bio fabricated nanoparticles were confirmed by surface plasmon resonance which were characterized by biophysical measures utilizing the ultraviolet-visible spectroscopy, scanning electron microscopy (SEM), energy dispersive X-ray, and transmission electron microscope (TEM), Fourier transform infrared spectroscopy, particle size analyzer, and X-ray diffraction. Antibacterial efficacy against Enterobacter aerogens, Proteus mirabilis, Escherichia coli, Staphylococcus epidermis, and Bacillus subtilis. The effect of SNPs tested against HepG2 and NIH/3T3 cell line exhibits a dose-dependent toxicity.

Results and Conclusion: The SEM and TEM images confirmed the presence of spherical and hexagonal shape (0.3-4 $\mu \mathrm{m})$ of nanocrystalline particles with the size range of $11.5-29.2 \mathrm{~nm}$. The average particles size of SNPs is $190.3 \pm 17.0 \mathrm{~nm}$. Antibacterial activity was carried out by agar well diffusion method against different pathogenic bacteria of which $B$. subtilis showed a significant zone of inhibition $8.66 \mathrm{~mm}$ and $12.0 \mathrm{~mm}$ for aqueous plant extract and synthesized SNPs. The effect of SNPs tested against HepG2 and NIH/3T3 cell line exhibits a dose-dependent toxicity. In case of HepG2, the cell viability was decreased to $50 \%$ ( IC $_{50}$ ) at the concentration of $173.8 \pm 0.84 \mu \mathrm{g} / \mathrm{mL}$. From the results, it can be concluded that the SNPs fabricated using green synthesis method will be a promising candidate in the biomedical field, due to its high bioactive properties.

Keywords: Silver nanoparticles, Trainthema portulacastrum, Antibacterial activity, Cytotoxic activity.

(C) 2017 The Authors. Published by Innovare Academic Sciences Pvt Ltd. This is an open access article under the CC BY license (http://creativecommons. org/licenses/by/4. 0/) DOI: http://dx.doi.org/10.22159/ajpcr.2017.v10i3.16216

\section{INTRODUCTION}

"In modern nanotechnology one of the most exciting areas is the interaction between inorganic quantum dots and biological structures" - This was the first report on the formation of gold nanoparticles from living plants, which opens up a new and exciting way to fabricate nanoparticles. It demonstrates the future possibilities to link material science and biotechnology in the newly emerging field of nanobiotechnology [1]. A great deal of effort has been continuing to develop environmentally benign synthesis processes that are free from toxic chemicals. Biosynthesis of nanoparticles has received great attention among researchers by employing either microorganisms or plant or animal extracts as a simple and viable alternative to chemical and physical methods. There are many diverse types of inorganic nanoparticles which are being synthesized from the biological sources, of which the amalgamation of silver nanoparticles (SNPs) has attracted much attention because of their exclusive shape-dependent, nonlinear optics, and optical receptor, good electrical activity, and chemical stability properties. Hence the SNPs were widely used for the manufacture of food products, cosmetics, biomaterials devices, medicine, and environmental remediation compounds. Especially in the biomedical fields such as anti-malarial, bio-labeling, antimicrobial, and cytotoxic properties of SNPs ensures a non-toxic biotherapeutic agent. In addition, green synthesized SNPs were applied in photographic reactions, catalysis, and chemical analysis [2-6].

Nanoparticle synthesis using physical and chemical methods include high pressure, energy, temperature, and toxic chemicals. Plant extracts are suitable for large scale biosynthesis of SNPs in a controlled manner according to their size shape and sensitivity. A survey of earlier literature explored high anticancer and antimicrobial properties for SNPs synthesized from the organic extracts of Westiellopsis sp., [4],
Alternanthera dentate [7], Achillea biebersteinii [8], Chrysopogon zizanioides [9], Cassia auriculata [10], Clitoria ternatea and Solanum nigrum [11], Acacia farnesiana [12], Rhynchotechum ellipticum [13], Brassica oleracea. var. botrytis. L [14], Mimosa pudica [15], Gloriosa superba [16], Chaetoceros calcitrans, Chlorella salina, Isochrysis galbana and Taterillus gracilis (marine micro algae) [17], Cocos nucifera [18], Catharanthus roseus [19], and wheat bran [20], so forth. In this study, the aqueous leaf extract of Trainthema portulacastrum, were reduced to SNPs in a concentrated aqueous solution of AgN03. These greensynthesized SNPs from T. portulacastrum were characterized. Besides, their antibacterial and anti-cancer efficacy of newly synthesized SNPs was examined in detail.

\section{METHODS}

\section{Chemicals}

Silver nitrate $\left(\mathrm{AgNO}_{3}\right)$ as analytical grade purchased from Merck Pvt., Ltd. All of the media components and analytical reagents were purchased from Hi-Media Laboratories Pvt., Ltd., (Mumbai, India). All the chemicals were of reagent grade and used without further purification.

\section{Microorganisms and cell lines}

Gram-negative - Enterobacter aerogens (MTCC 111), Proteus mirabilis (ATCC 49565), Escherichia coli (ATCC 25922), and Grampositive - Staphylococcus epidermis (MTCC 3615), B. subtilis (MTCC 441) were used for antibacterial activity experiment, and the microbial cultures were obtained from the Department of Microbiology, Christian Medical College, Vellore, Tamil Nadu, India. For cell culture studies, the mouse embryonic fibroblast cell line (NIH/3T3) and human (Homo sapiens) liver hepatocellular carcinoma (HepG2) was obtained from the National Center for Cell Science (Pune, India). 


\section{Plant material}

The leaves of T. portulacastrum were collected from Ranchi, Jharkhand, India. The plant was identified, confirmed, and authenticated by Professor P. Jayaraman, Scientist, Ph.D., Chennai, India (Reg No. PARC/2015/3016). T. portulacastrum is a habit dicot belonging to the family Aizoaceae, is one of the common weeds, which is traditionally used to cure diseases. In India, both the red and green biotypes grow best under minimal shade and flourish in neutral to alkaline soils that are low in organic matter. The plant grows in sunny and dry areas along roadside, in wastelands and gardens [21].

\section{Preparation of plant materials}

Fresh leaves of T. portulacastrum, free from diseases were collected in air-tight bags and then washed thoroughly 2-3 times with tap water, surface sterilized with $0.1 \% \mathrm{HgCl}_{2}$ for 1 minute to reduce microbial contamination and once with sterile water [22]. The finely chopped $20 \mathrm{~g}$ of fresh leaves were added to $100 \mathrm{~mL}$ of deionized water and stirred at $60^{\circ} \mathrm{C}$ for 30 minutes. After boiling, the mixture was cooled and filtered with Whatman paper number-1. Filtrate was collected, and the aqueous extract was stored at $4{ }^{\circ} \mathrm{C}$ until further use.

\section{Synthesis of SNPs}

Various concentrations $(1,3,5$ and $10 \mathrm{mM})$ of aqueous AgNO3 was prepared and used for the synthesis of SNPs. In 1, 3, and $5 \mathrm{~mL}$ of aqueous leaf extract of $T$. portulacastrum $10 \mathrm{~mL}$ of $1,3,5$, and 10 mM AgNO3 solution was added in the ratio of $1: 10,3: 10$, and 5:10 to occur bioreduction process. The color change was observed from light yellowish to brown, when kept in dark at room temperature and further monitored by measuring ultraviolet-visible (UV-VIS) spectra of the reaction mixture.

\section{Characterization of synthesized SNPs}

Synthesis of SNPs was initially confirmed by position of surface plasmon resonance (SPR) band was measured by aqueous SNPs using SL-210 double beam UV-VIS spectrophotometer with $1.8 \mathrm{~nm}$ bandwidth at different wavelengths from 300 to $600 \mathrm{~nm}$. Crystal structure of dried SNPs was characterized by X-ray diffractometer (XRD), the scanning mode was continuous with the scanning range (2) from 10 to $90^{\circ}$ pattern was carried out by Rigaku model ZSX PRIMUS III. The shape, size and elemental composition of dried SNPs were subjected to scanning electron microscope (SEM)-energy dispersive X-ray spectroscopy (EDX) using HITACHI model S-2400. For transmission electron microscope (TEM), drop of aqueous SNPs sample was loaded on a carbon-coated copper grid, and it was allowed to dry in room temperature, the micrographs were obtained using TECNAI model G2-ST $200 \mathrm{kV}$. The average particle size distribution was determined by particle size analyzer (PSA), AIM SIZER model AS-2011 particle sizing spectrophotometer. The Fourier Transform Infrared Spectroscopy (FT-IR) spectrum of SNPs and aqueous extract was carried out using IR AFFINITY-1S spectrophotometer by employing $\mathrm{KBr}$ pellet technique in the transmission mode of $500-4,000 \mathrm{~cm}^{-1}$.

\section{Antibacterial activity}

The antibacterial activity of synthesized SNPs was performed using agar well diffusion method against pathogenic bacterial strains, E. aerogens, P. mirabilis, E. coli, S. epidermis and B. subtilis. From the fresh culture, $100 \mu \mathrm{L}$ of each strain was swabbed uniformly onto the individual plates containing sterile Muller Hinton agar and wells were made with the diameter of $6 \mathrm{~mm}$. Then, $20 \mathrm{~L}$ of samples (purified SNPs, aqueous leaf extract, and $\mathrm{AgNO}_{3}$ solution) were prepared in deionized water and poured into each well. In addition, the commercial antibiotic discs Gentamicin $(30 \mu \mathrm{g} / \mathrm{disc})$ were placed as positive control and incubated for $24 \mathrm{hrs}$ at $37^{\circ} \mathrm{C}$. After incubation, the different levels of zonation formed around the well were measured using a Hi-Media meter ruler. This experiment was repeated for three times. The data generated were expressed as a mean \pm SD [23-25].

\section{Anticancer property}

Cell viability of NIH/3T3 and HepG2 was measured using the MTT (3- [4, 5-dimethylthiazol-2-yl]-2, 5-diphenyltetrazolium bromide) dye-reduction assay to determine the cytotoxic effect of the SNPs at various concentrations. Briefly, the cells were plated onto 96 -well flatbottom culture plates with cell density of $5.0 \times 10^{3}$ cells per well and the plates were incubated for $24 \mathrm{hrs}$ for the adherent of cells. To the wells, various test concentrations of SNPs (50-450 $\mu \mathrm{g} / \mathrm{mL})$ and Metformin (10 $\mathrm{mM}$ ) standard drug as a positive control were added. The plates were incubated at required period at $37^{\circ} \mathrm{C}, 5 \% \mathrm{CO}_{2}$ in a humid atmosphere, $10 \mu \mathrm{L}$ of MTT ( $5 \mathrm{mg} / \mathrm{mL}$ in PBS) was added to each well, and the plate was incubated for a further $4 \mathrm{hrs}$ at $37^{\circ} \mathrm{C}$. The resulting formazan was dissolved in $100 \mu \mathrm{L}$ of Dimethyl-sulfoxide with gentle shaking at $37^{\circ} \mathrm{C}$, and absorbance was measured at $570 \mathrm{~nm}$ with an enzyme-linked immunosorbent assay reader (BioTek model ELx800) [26-29]. The results were given as the means of three independent experiments. Concentrations of SNPs showing a $50 \%$ reduction in cell viability (i.e. half-maximal inhibitory concentration $\left[\mathrm{IC}_{50}\right]$ values) was performed using GraphPad Prism version 5.01 for Windows, GraphPad Software, San Diego California USA, www.graphpad.com.

\section{Statistical analysis}

Data were expressed as mean \pm SD. Statistical analysis was performed using IBM SPSS Statistics Version 21.0. IC50 value was calculated using GraphPad Prism version 5.01.

\section{RESULTS AND DISCUSSION}

\section{Visual observation and UV-VIS spectroscopy analysis}

The addition of T. portulacastrum leaf extract to $\mathrm{AgNO}_{3}$ solution resulted in color change of the solution from transparent yellowish to colloidal brown due to the production of SNPs. The color changes occurred from the excitation of surface plasmon vibrations with the SNPs produced a peak centered near $420 \mathrm{~nm}$ were studied using UV-VIS spectroscopy [30]. Effect of concentration parameter was optimized including the concentration of $\mathrm{AgNO}_{3}$ and aqueous T. portulacastrum leaf extract. Various concentrations $(1,3$ and $5 \mathrm{~mL})$ of leaf extracts were added to $\mathrm{AgNO}_{3}$ solution to maintain its $10 \mathrm{~mL}$ concentration $(1,3,5$ and $10 \mathrm{mM})$. After the incubation period, the reaction mixture was scanned in the range of $350-600 \mathrm{~nm}$, a major absorbance peak around 390-455 nm is observed in Fig. 1. The results were agreement with the SNP synthesized from saccharose, maltose, and olive leaf extracts, which displayed the characteristic peak in the range of $440-458 \mathrm{~nm}[31,32]$. The broad peak is due to the anisotropic nature of the SNPs. It has been reported that the band in this broad region corresponds to the surface plasmon resonance of SNPs [33].

\section{XRD analysis}

The crystalline nature of as prepared SNPs was studied by XRD analysis represented in Fig. 2. It is apparent that the characteristic peaks at $38.45^{\circ}, 44.48^{\circ}, 64.69^{\circ}$, and $77.62^{\circ}$ were corresponds to the lattice planes (111), (200), (220) and (311), respectively (JCPDS No. 01-1167 and 01-1164). These results confirmed the face-centered-cubic structure of SNPs [25].

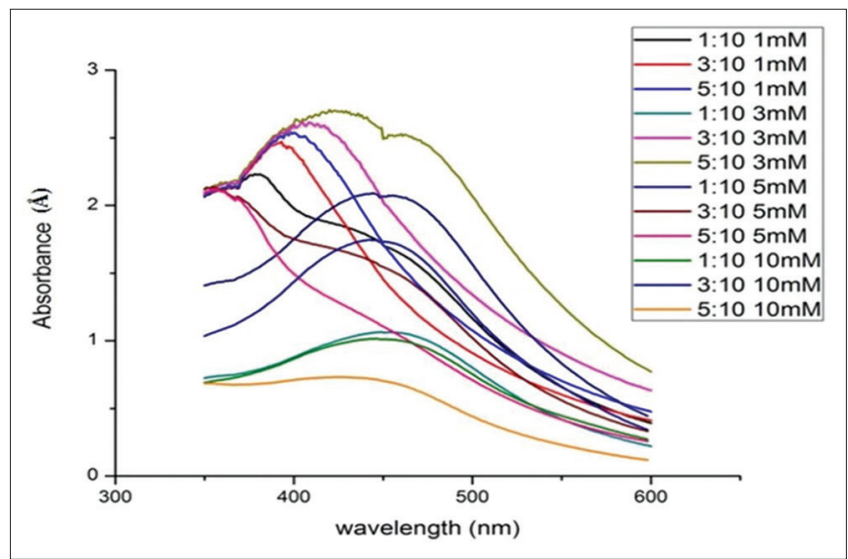

Fig. 1: Effect of silver nitrate $(1,3,5$ and $10 \mathrm{mM})$ and aqueous extract $(1,3$, and $5 \mathrm{~mL})$ concentration on silver nanoparticles formation 
SEM with EDX spectroscopy analysis

To gain additional insight into the features of the SNPs, morphology and elemental analysis of the sample was performed using SEM-EDX techniques. It reveals that most of the SNPs are predominantly spherical in shape, whereas some of the nanoparticles were found to be having structures of irregular shape such as hexagonal, cubical, and triangular as shown in Fig. 3(a-c and e,f). It is known that the morphology of metal nanoparticles considerably changes their optical and electronic properties $[34,35]$. The breadth and width of the single agglomeration are $5.489 \mu \mathrm{m}$ and $4.528 \mu \mathrm{m}$ (Fig. $3 \mathrm{~d}$ ) in $5 \mu \mathrm{m}$ magnification of 20,000 X. The EDX spectrum evident the SNPs prepared by bioreduction method as indicated in Fig. 4 and Table 1 . The signal at $3.40 \mathrm{keV}$ strongly suggests the corresponding binding energies of AgL was the element of these NPs, as it has optical absorption in this range due to the SPR [36]. The other signals (carbon and oxygen) indicate the presence of plant extract, which corresponds to the biomolecules that were capping over the SNPs.

\section{TEM analysis}

The TEM characterization has been used to identify the size, shape, and morphology of nanoparticles, as shown in Fig. 5. The nanoparticles

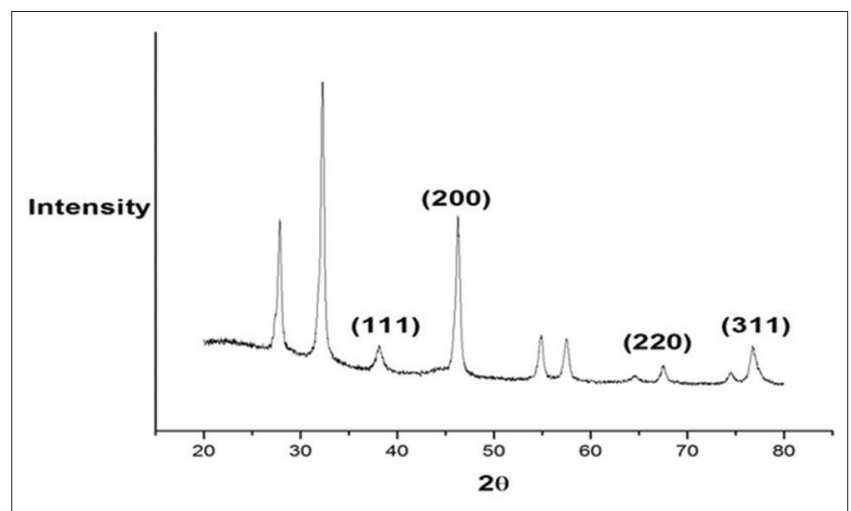

Fig. 2: X-ray diffractometer analysis of Trainthema portulacastrum leaf extract mediated synthesized

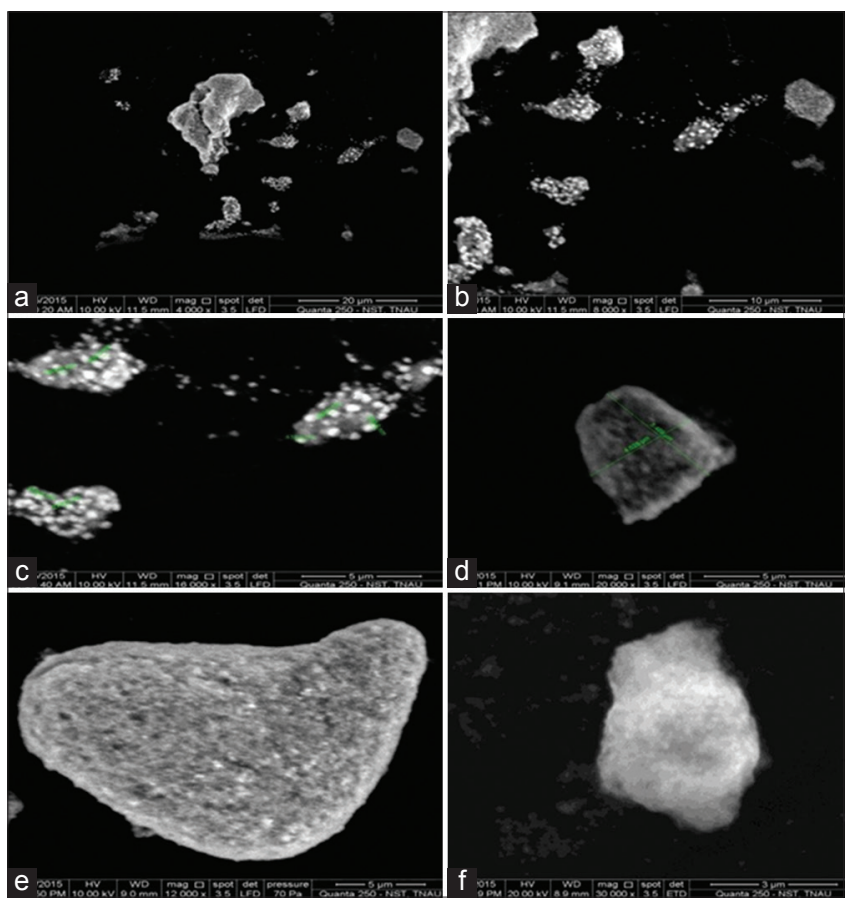

Fig. 3: (a-f) Morphology of silver nanoparticles showed by scanning electron microscopy are homogeneous and spherical which confirms the shape of SPR band in the UV-VIS spectrum [37]. The particle size ranges with an average diameter of around 11.5-29.2 $\mathrm{nm}$. The particle size determined by TEM is an actual diameter of the NPs as it is measured at the dried state of the sample, whereas the size measured by PSA is a hydrodynamic diameter (hydrated state). Therefore, the NPs will have a larger hydrodynamic volume due to the solvent effect in the hydrated state [38]. Thus, the size of the synthesized SNPs observed by the TEM method is less than the size measured by the PSA method.

\section{PSA}

The PSA technique is used to determine the average particle size of small particles in suspension. The average particles size distribution of SNPs having a mean \pm SD particle size of $\sim 190.3 \pm 17.0 \mathrm{~nm}$ (Fig. 6). The previous result corresponds to the synthesis of silver sub-micro and nanoparticles of p-tert-butyl thiacalix [23] arenes and amla extract for antiproliferative property, which showed an average particle size distribution with $\sim 188 \mathrm{~nm}[39,40]$.

\section{FT-IR spectroscopy analysis}

The FT-IR spectrum obtained for SNPs synthesized by T. portulacastrum aqueous leaf extract (Fig. 7a) shows a strong band at $3405.47 \mathrm{~cm}^{-1}$ could be assigned to the $\mathrm{N}-\mathrm{H}$ stretching vibrations of amide group. The FT-IR spectrum also showed narrow small bands at 3743.99 and $3838.51 \mathrm{~cm}^{-1}$ which was identified as phenols. The absorption band at $2414.02 \mathrm{~cm}^{-1}$ could be attributed to the vibrations of aldehydes. Moreover, the absorption peaks at 1526.72 and $1638.6 \mathrm{~cm}^{-1}$ result from the bending of $\mathrm{C}=\mathrm{C}$ aromatic group [41]. The FT-IR spectrum obtained for $T$. portulacastrum aqueous leaf extract (Fig. $7 \mathrm{~b}$ ) displayed a number of absorption peaks, reflecting its complex nature. Strong absorption peaks at $3,458.52 \mathrm{~cm}^{-1}$ result from stretching of the $-\mathrm{OH}$ hydroxyl or phenol group. The absorption peaks at about $1640.53 \mathrm{~cm}^{-1}$ could be assigned to stretching vibrations of $-\mathrm{C}=\mathrm{C}$ - is the functional group for alkenes. The peaks at 669.33 to $445.58 \mathrm{~cm}^{-1}$ indicate the fingerprint

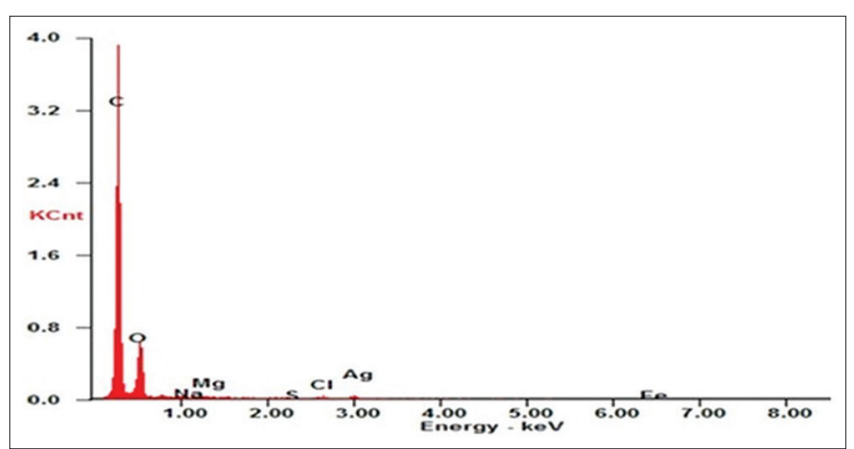

Fig. 4: Spectrum of elemental analysis of silver nanoparticles using leaf extract of Trainthema portulacastrum

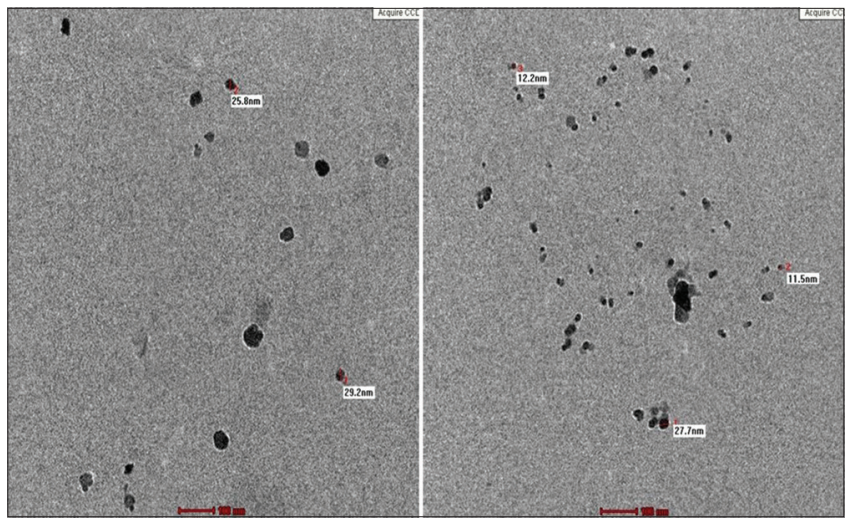

Fig. 5: Transmission electron microscope analysis of synthesized silver nanoparticles shows well dispersed spherical shape nature 
region for stretching of $\mathrm{C}-\mathrm{Br}$ for alkyl halides groups. FT-IR study indicated that the carboxyl $(-\mathrm{C}=0)$, hydroxyl $(-\mathrm{OH})$, and amine $(\mathrm{N}-\mathrm{H})$ groups in T. portulacastrum leaf extract are mainly involved in the reduction of Ag+ ions to SNPs. The observed peaks are mainly ascribed to flavonoids, alkaloids, phenols, and terpenoids were excessively present in plant extracts $[42,43]$. The results are in good concurrence with those found in literature [44]. The carbonyl group of amino acid residues has a strong binding ability with metal, suggesting the formation of a layer of bioorganic compounds covering SNPs and acts as a stabilizing agent to prevent aggregation in the aqueous medium.

\section{Antibacterial analysis}

Antibacterial activity of the synthesized SNPs was studied using five different bacteria, namely E. aerogens, P. mirabilis, E. coli, S. epidermis

Table 1: Composition of elemental analysis

\begin{tabular}{lll}
\hline Element & Wt\% & At\% \\
\hline C K & 71.35 & 78.94 \\
O K & 24.33 & 20.21 \\
NaK & 00.09 & 00.05 \\
MgK & 00.05 & 00.03 \\
S K & 00.19 & 00.08 \\
ClK & 00.79 & 00.30 \\
AgL & 03.20 & 00.39 \\
\hline
\end{tabular}

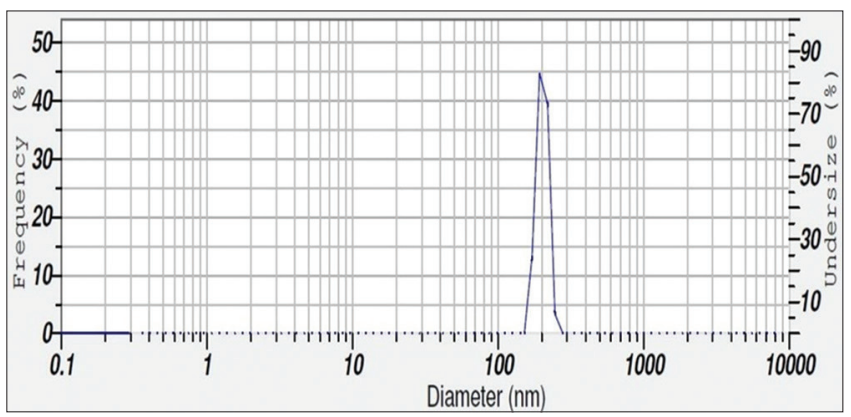

Fig. 6: Particle size analyzer analysis of synthesized silver nanoparticles and B. subtilis. SNPs exhibited excellent activity against E. aerogens, P. mirabilis, S. epidermis and B. subtilis. The triplicate mean zone of inhibition for silver SNPs ranged from $12.0 \pm 0.65$ to $13.93 \pm 0.62 \mathrm{~mm}$, as shown in Table 2. The antibacterial effect was more evident in Gramnegative bacteria than Gram-positive bacteria [45]. The antimicrobial activity of SNPs is influenced by the particle dimensions [46]. Silver has long been documented as having an inhibitory effect on microbes present in medical and industrial process. The most important use of silver and SNPs is in medical industry, such as in topical ointments to prevent infection against burns and open wounds [47]. They bind closely to the exterior cell wall of microorganisms, causing in evidence damage to cells, with complete eruption of flagella, stimulated the production of biofilm and aggregation within the biofilm [48]. We ascribe the higher activity of SNPs to their small size. The smaller particles with 1-10 nm have greater antimicrobial effects [49]. The antimicrobial activity in the present study was much higher when compared with previous reports. SNPs synthesized from Trianthema decandra, Polyalthia longifolia, Eucalyptus chapmaniana, Embelia ribes, Psoralea corylifolia, Melia azadirachta, Smilax china, Berberis aristata, Balsamodendron mukul, Acorus calamus, Glycyrrhiza glabra, carob leaf extract [50], Solanum trilobatum [51] and Andropogon muricatus showed activity against $E$. coli, $P$. aeruginosa, S. aureus, and C. albicans $[45,46,49,52]$. The results of the present study are investigative of prominent antibacterial effects. They provide an important basis for SNPs synthesized from the aqueous leaf extract of T. portulacastrum in the treatment of infections related with the microorganisms used in this study. These might prove to be important leads for the development and discovery of new antimicrobial drugs.

\section{Anticancer analysis}

To evaluate cytotoxicity of SNPs, the cells (NIH/3T3 mouse embryonic fibroblast cell line and HepG2 human liver HepG2 cell line) were treated with varying concentrations of SNPs $(50,150,250,350$ and $450 \mu \mathrm{g} / \mathrm{mL}$ ) for $24 \mathrm{hrs}$. There is a significant percentage of cell viability of $64.05 \%$ even at a higher concentration of $450 \mu \mathrm{g} / \mathrm{mL}$ to NIH/3T3 cell line (Fig. 8a). Previous studies on NIH/3T3 cell line using brown seaweed Sargassum muticum aqueous extract showed no toxicity at 24 hrs [53]. The cell viability was reduced in a dose-dependent manner in HepG2 cell line, and the IC50 of the nanoparticles was observed at concentrations of $173.8 \pm 0.84 \mu \mathrm{g} / \mathrm{mL}$. The cell viability was reduced by $15.84 \%$ for HepG2 cell line at $450 \mu \mathrm{g} / \mathrm{ml}$ concentration (Fig. 8b).



Fig. 7: Fourier Transform Infrared Spectroscopy spectrum of (a) silver nanoparticles synthesized by Trainthema portulacastrum aqueous leaf extract and (b) Trainthema portulacastrum aqueous leaf extract 
Table 2: Diameter of inhibition zone of T. portulacastrum aqueous plant extract and

\begin{tabular}{llll}
\hline \multirow{2}{*}{ Tested microorganisms } & \multicolumn{2}{l}{ Inhibition zone (mm in diameter) } & \\
\cline { 2 - 4 } & Aqueous plant extract & Silver nanoparticle & Ag+ions \\
\hline Enterobacter aerogens & NA & $13.93 \pm 0.62$ & $10.2 \pm 0.40$ \\
Proteus mirabilis & NA & $12.86 \pm 0.50$ & $8.76 \pm 0.35$ \\
Escherichia coli & NA & $9.75 \pm 0.40$ & $9.44 \pm 0.25$ \\
Staphylococcus epidermis & NA & $13.45 \pm 1.10$ & $7.4 \pm 0.35$ \\
Bacillus subtilis & $8.66 \pm 0.763$ & $12.0 \pm 0.65$ & $214.33 \pm 0.4$ \\
\hline
\end{tabular}

E. aerogens: Enterobacter aerogens, E. coli: Escherichia coli, S. epidermis: Staphylococcus epidermis, B. subtilis: Bacillus subtilis, T. portulacastrum: Trainthema portulacastrum

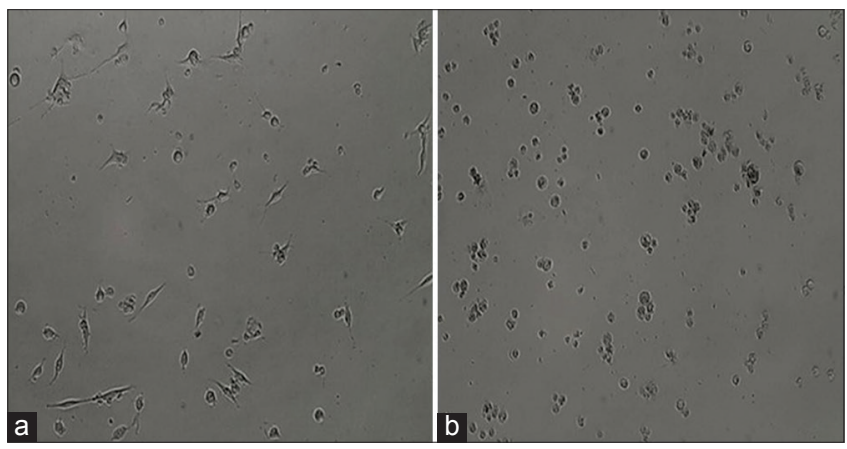

Fig. 8: Anticancer activity of $450 \mu \mathrm{g} / \mathrm{mL}$ silver nanoparticles against (a) NIH/3T3 and (b) HepG2 cell lines

Moreover, $11.4 \pm 3.52 \mathrm{~nm}$ size synthesized SNP from Pterocladiella capillacea showed IC50 of $3.7 \mu \mathrm{g} / \mathrm{mL}$ [54], volume of the nanoparticle is always proportional to the activity of the nanoparticles. The synthesized SNPs showed no significant activity to the NIH/3T3 but have toxicity toward cancer cell line HepG2. When compounds have anti- cancerous activity are capped with AgNPs, it enhance its apoptotic property as a novel approach for cancer therapy [55]. Since AgNPs can be used in an escalating number of applications, further studies on the mechanisms of AgNPs uptake and cytotoxicity studies are required to rate the risks and benefits of nano-silver [39].

\section{CONCLUSION}

The present study reported the synthesis of SNPs by T. portulacastrum aqueous leaf extract without using any harmful reducing or capping agents, as confirmed by UV-VIS spectrophotometer, XRD, TEM, SEMEDX, PSA, and FT-IR techniques. Spherical, hexagonal, smooth surface and polydispersed particles of size ranging from 11.5 to $29.2 \mathrm{~nm}$ with an average size of $\sim 190.3 \pm 17.0 \mathrm{~nm}$ were obtained. The lowest inhibition zone $(\mathrm{mm})$ of the AgNPs was exhibited against $E$. coli. The effect of SNPs on HepG2 human liver HepG2 cell line exhibits a dosedependent toxicity, and the viability of HepG2 cells decreased to $50 \%$ $\left(\mathrm{IC}_{50}\right)$ at the concentration of $173.8 \pm 0.84 \mu \mathrm{g} / \mathrm{mL}$. The synthesized AgNPs act as excellent bactericidal agent and without exhibiting any toxic effects on mouse embryonic fibroblast cells NIH/3T3. In future, T. portulacastrum synthesized SNPs can be used as a targeted therapy towards cancer and other human diseases due to their no toxicity for non-cancerous cell line.

\section{ACKNOWLEDGMENTS}

The authors would like to thank the Tamil Nadu Agriculture University, Coimbatore, Tamil Nadu, India for characterization, and Christian Medical College, Vellore, Tamil Nadu, India for providing microorganisms and our parents for financial support.

\section{REFERENCES}

1. Gardea-Torresdey JL, Parson JG, Gomez E, Peralta-Videa J, Troiani HE, Santiago $\mathrm{P}$, et al. Formation and growth of Au nanoparticles in live side live Alfalfa plants. Nano Lett 2002;2:397-401.

2. Claus P, Hofmeister H. Electron microscopy and catalytic study of silver catalysts: Structure sensitivity of the hydrogenation of crotonaldehyde. J Phys Chem B 1999;103(14):2766-75.

3. Corrêa JM, Mori M, Sanches HL, da Cruz AD, Poiate E Jr, Poiate IA. Silver nanoparticles in dental biomaterials. Int J Biomater 2015;2015:485275.

4. Lakshmi PT, Priyanka D, Annamalai A. Reduction of silver ions by cell free extracts of Westiellopsis sp. Int J Biomater 2015;2015:539494.

5. Martinez-Gutierrez F, Olive PL, Banuelos A, Orrantia E, Nino N, Sanchez EM, et al. Synthesis, characterization, and evaluation of antimicrobial and cytotoxic effect of silver and titanium nanoparticles. Nanomedicine 2010;6(5):681-88.

6. Sharma VK, Yngard RA, Lin Y. Silver nanoparticles: Green synthesis and their antimicrobial activities. Adv Colloid Interface Sci 2009;145(1-2):83-96.

7. Kumar DA, Palanichamy V, Roopan SM. Green synthesis of silver nanoparticles using Alternanthera dentata leaf extract at room temperature and their antimicrobial activity. Spectrochim Acta A Mol Biomol Spectrosc 2014;127:168-71.

8. Baharara J, Namvar F, Ramezani T, Hosseini N, Mohamad R. Green synthesis of silver nanoparticles using Achillea biebersteinii flower extract and its anti-angiogenic properties in the rat aortic ring model. Molecules 2014;19(4):4624-34.

9. Arunachalam KD, Annamalai SK. Chrysopogon zizanioides aqueous extract mediated synthesis, characterization of crystalline silver and gold nanoparticles for biomedical applications. Int J Nanomedicine 2013;8:2375-84

10. Sahana R, Daniel SC, Sankar SG, Archunan G, Vennison SJ, Sivakumar M. Formulation of bactericidal cold cream against clinical pathogens using Cassia auriculata flower extract-synthesized Ag nanoparticles. Green Chem Lett Rev 2014;7(1):64-72.

11. Krithiga N, Rajalakshmi A, Jayachitra A. Green synthesis of silver nanoparticles using leaf extracts of Clitoria ternatea and Solanum nigrum and study of its antibacterial effect against common nosocomial pathogens. J Nanosci 2015;2015:1-8.

12. Yallappa S, Manjanna J, Peethambar SK, Rajeshwara AN, Satyanarayan ND. Green synthesis of silver nanoparticles using Acacia farnesiana (sweet acacia) seed extract under microwave irradiation and their biological assessment. J Cluster Sci 2013;24(4):1081-92.

13. Deepshikha H, Alakesh P, Eramoni S, Bolin C. Phytochemical screening and synthesis of silver nanoparticles using leaf extract of Rhynchotechum ellipticum. Int J Pharm Pharm Sci 2014;6(1):672-74.

14. Ranjitham AM, Suja R, Caroling G, Tiwari S. In vitro evaluation of antioxidant, antimicrobial, anticancer activities and characterisation of Brassica oleracea. Var. Bortrytis. 1 synthesized silver nanoparticles. Int J Pharm Pharm Sci 2013;5(4):239-54.

15. Raj RS, Divya S, Sindhu S, Kasinathan K, Arumugam P. Studies on synthesis, characterization and application of silver nanoparticles using Mimosa pudica leaves. Int J Pharm Pharm Sci 2014;6(2):453-55.

16. Ashokkumar S, Ravi S, Velmurugan S. Green synthesis of silver nanoparticles from Gloriosa superba L. Leaf extract and their catalytic activity. Spectrochim Acta A Mol Biomol Spectrosc 2013;115:388-92.

17. Merin DD, Prakash S, Bhimba BV. Antibacterial screening of silver nanoparticles synthesized by marine micro algae. Asian Pac J Trop Med 2010;3(10):797-99.

18. Mariselvam R, Ranjitsingh AJ, Usha Raja Nanthini A, Kalirajan K, Padmalatha C, Mosae Selvakumar P. Green synthesis of silver nanoparticles from the extract of the inflorescence of Cocos nucifera (Family: Arecaceae) for enhanced antibacterial activity. Spectrochim Acta A Mol Biomol Spectrosc 2014;129:537-41.

19. Ghozali SZ, Vuanghao L, Ahmad NH. Biosynthesis and characterization of silver nanoparticles using Catharanthus roseus leaf extract and its proliferative effects on cancer cell lines. J Nanomed Nanotechnol 2015;6:305. 
20. Gupta S, Jangir OP, Sharma M. The green synthesis, characterization and evaluation of antioxidant and antimicrobial efficacy of silver and gold nanospheres synthesized using wheat bran. Asian J Pharm Clin Res 2016;9(6):103-5.

21. Chandra VS. Phytochemical studies on leaves of Trianthema portulacastrum L. BIOS 2013;1:67-73.

22. Singh V, Tyagi A, Chauhan PK, Kumari P, Kaushal S. Identification and prevention of bacterial contamination on explant used in plant tissue culture labs. Int J Pharm Pharm Sci 2011;3(4):160-63.

23. Aziz N, Fatma T, Varma A, Prasad R. Biogenic synthesis of silver nanoparticles using Scenedesmus abundans and evaluation of their antibacterial activity. J Nanopart 2014;2014:6.

24. Shankar KG, Fleming TA, Vidhya R, Pradhan N. Synergistic efficacy of three plant extracts, Bergenia ciliata, Acorus calamus and Dioscorea bulbifera for antimicrobial activity. Int J Pharm Bio Sci 2016;7(4):(B)619-28.

25. Arokiyaraj S, Arasu MV, Vincent S, Prakash NU, Choi SH, Oh YK, et al. Rapid green synthesis of silver nanoparticles from Chrysanthemum indicum $\mathrm{L}$ and its antibacterial and cytotoxic effects: An in vitro study. Int J Nanomedicine 2014;9:379-88

26. Lee YH, Cheng FY, Chiu HW, Tsai JC, Fang CY, Chen CW, et al. Cytotoxicity, oxidative stress, apoptosis and the autophagic effects of silver nanoparticles in mouse embryonic fibroblasts. Biomaterials 2014;35(16):4706-15.

27. Gurunathan S, Raman J, Abd Malek SN, John PA, Vikineswary S. Green synthesis of silver nanoparticles using Ganoderma neojaponicum Imazeki: A potential cytotoxic agent against breast cancer cells. Int J Nanomedicine 2013;8:4399-413.

28. Kawata K, Osawa M, Okabe S. In vitro toxicity of silver nanoparticles at noncytotoxic doses to HepG2 human hepatoma cells. Environ Sci Technol 2009; 43(15):6046-51.

29. Syed A, Saraswati S, Kundu GC, Ahmad A. Biological synthesis of silver nanoparticles using the fungus Humicola sp. and evaluation of their cytoxicity using normal and cancer cell lines. Spectrochim Acta A Mol Biomol Spectrosc 2013;114:144-7.

30. Veerasamy R, Xin TZ, Gunasagaran S, Xiang TF, Yang EF, Jeyakumar N, et al. Biosynthesis of silver nanoparticles using mangosteen leaf extract and evaluation of their antimicrobial activities. J Saudi Chem Soc 2011;15(2):113-20

31. Filippo E, Serra A, Buccolieri A, Manno D. Green synthesis of silver nanoparticles with sucrose and maltose: Morphological and structural characterization. J Non Cryst Solids 2010;356(6-8):344-50.

32. Khalil MM, Ismail EH, El-Baghdady KZ, Mohamed D. Green synthesis of silver nanoparticles using olive leaf extract and its antibacterial activity. Arabian J Chem 2014;7(6):1131-9.

33. Maciollek A, Ritter H. One pot synthesis of silver nanoparticles using a cyclodextrin containing polymer as reductant and stabilizer. Beilstein J Nanotechnol 2014;5(1):380-5

34. Xu H, Kall M. Morphology effects on the optical properties of silver nanoparticles. J Nanosci Nanotechnol 2002;4(3):254-9.

35. Chandran SP, Chaudhary M, Pasricha R, Ahmad A, Sastry M. Synthesis of gold nanotriangles and silver nanoparticles using Aloe vera plant extract. Biotechnol Prog 2006;22(2):577-83.

36. Banu AN, Balasubramanian C, Moorthi PV. Biosynthesis of silver nanoparticles using Bacillus thuringiensis against dengue vector, Aedes aegypti (Diptera: Culicidae). Parasitol Res 2014;113(1):311-6.

37. Mollick MM, Rana D, Dash SK, Chattopadhyay S, Bhowmick B, Maity D, et al. Studies on green synthesized silver nanoparticles using Abelmoschus esculentus (L.) Pulp extract having anticancer (in vitro) and antimicrobial applications. Arabian J Chem 2015. DOI: 10.1016/j. arabjc.2015.04.033
38. Gao FP, Zhang HZ, Liu LR, Wang YS, Jiang Q, Yang XD, et al. Preparation and physicochemical characteristics of self-assembled nanoparticles of deoxycholic acid modified carboxymethyl curdlan conjugates. Carbohydr Polym 2008;71:606-13.

39. Rosarin FS, Arulmozhi V, Nagarajan S, Mirunalini S. Antiproliferative effect of silver nanoparticles synthesized using amla on Hep2 cell line. Asian Pac J Trop Med 2013;6(1):1-10.

40. Stoikov II, Yushkova EA, Antipin IS, Konovalov AI. Synthesis of silver and lithium sub-micro-and nanoparticles coated with derivatives of p-tert-butyl thiacalix[4]arenes. J Nanopart Res 2011;13(12):6603-11.

41. Satyavani K, Gurudeeban S, Ramanathan T, Balasubramanian T. Biomedical potential of silver nanoparticles synthesized from calli cells of Citrullus colocynthis (L.) Schrad. J Nanobiotechnology 2011;9:43.

42. Banerjee P, Satapathy M, Mukhopahayay A, Das P. Leaf extract mediated green synthesis of silver nanoparticles from widely available Indian plants: Synthesis, characterization, antimicrobial property and toxicity analysis. Bioresour Bioprocess 2014;1(3):1-10.

43. Prathna TC, Chandrasekaran N, Raichur AM, Mukherjee A. Biomimetic synthesis of silver nanoparticles by Citrus limon (lemon) aqueous extract and theoretical prediction of particle size. Colloids Surf B Biointerfaces 2011;82(1):152-9.

44. Pourmortazavi SM, Taghdiri M, Makari V, Rahimi-Nasrabadi M. Procedure optimization for green synthesis of silver nanoparticles by aqueous extract of Eucalyptus oleosa. Spectrochim Acta A Mol Biomol Spectrosc 2015;136:1249-54.

45. Sulaiman GM, Mohammed WH, Marzoog TR, Al-Amiery AA, Kadhum AA, Mohamad AB. Green synthesis, antimicrobial and cytotoxic effects of silver nanoparticles using Eucalyptus chapmaniana leaves extract. Asian Pac J Trop Biomed 2013;3(1):58-63.

46. Kaviya S, Santhanalakshmi J, Viswanathan B. Green synthesis of silver nanoparticles using Polyalthia longifolia leaf extract along with D-sorbitol: Study of antibacterial activity. J Nanotechnol 2011;2011:1-5.

47. Morones JR, Elechiguerra JL, Camacho A, Holt K, Kouri JB, Ramírez JT, et al. The bactericidal effect of silver nanoparticles. Nanotechnology 2005;16(10):2346-53.

48. Ghosh P, Han G, De M, Kim CK, Rotello VM. Gold nanoparticles in delivery applications. Adv Drug Deliv Rev 2008;60(11):1307-15.

49. Prashanth S, Menaka I, Muthezhilan R, Kumar SN. Synthesis of plant-mediated silver nano particles using medicinal plant extract and evaluation of its anti microbial activities. Int J Eng Sci Technol 2011;3:6235-50.

50. Awwad AM, Salem NM, Abdeen AO. Green synthesis of silver nanoparticles using carob leaf extract and its antibacterial activity. Int $\mathrm{J}$ Ind Chem 2013;4(29):2-7.

51. Vanaja M, Paulkumar K, Gnanajobitha G, Rajeshkumar S, Malarkodi C, Annadurai G. Herbal plant synthesis of antibacterial silver nanoparticles by Solanum trilobatum and its characterization. Int J Met 2014;2014:8.

52. Geethalakshmi R, Sarada DV. Gold and silver nanoparticles from Trianthema decandra: Synthesis, characterization, and antimicrobial properties. Int J Nanomedicine 2012;7:5375-84

53. Namvar F, Rahman HS, Mohamad R, Azizi S, Tahir PM, Chartrand MS, et al. Cytotoxic effects of biosynthesized zinc oxide nanoparticles on murine cell lines. Evid Based Complement Alternat Med 2015;2015:593014.

54. El Kassas HY, Attia AA. Bactericidal application and cytotoxic activity of biosynthesized silver nanoparticles with an extract of the red seaweed Pterocladiella capillacea on the HepG2 cell line. Asian Pac J Cancer Prev 2014;15(3):1299-306.

55. Vaidyanathan R, Kalishwaralal K, Gopalram S, Gurunathan S. Nanosilver - The burgeoning therapeutic molecule and its green synthesis. Biotechnol Adv 2009;27(6):924-37. 